\title{
O memorial: continuação da obra redentora de Jesus Cristo
}

\author{
Orientador: Luiz Fernando Ribeiro Santana \\ Mestrando: Celio da Silveira Calixto Filho \\ Área de Concentração: Teologia Sistemático-Pastoral \\ Linha de Pesquisa: Fé e Cultura
}

Dentre os elementos da liturgia cristã, o memorial é de grande importância, uma vez que atualiza os feitos divinos ao longo da história da salvação, trazendo para hoje sua força redentora, e abrindo aos participantes do culto uma perspectiva de futuro. $\mathrm{O}$ memorial está ligado estreitamente à Aliança de Deus com Abraão e sua descendência, que atinge seu ponto alto em Jesus Cristo. O passo seguinte se verifica nas realidades sacramentais, nos quais a comunidade dos fiéis experimenta a salvação. Percorrendo, portanto, a etapas da economia salvífica, pode-se perceber o memorial como continuação da obra redentora de Cristo, redentor único e universal.

Palavras-chave: Teologia litúrgica; memorial; Aliança. 